\title{
Rotifer communities under variable predation-turbulence combinations
}

\author{
Jukka Horppila • Laura Härkönen · Noora Hellén · Satu Estlander • \\ Zeynep Pekcan-Hekim • Anne Ojala
}

Received: 12 August 2018/Revised: 30 October 2018/Accepted: 2 November 2018/Published online: 11 November 2018

(C) The Author(s) 2018

\begin{abstract}
The effects of water turbulence on rotifer communities were experimentally studied under different predation pressures. When the larvae of the phantom midge (Chaoborus flavicans) were present in turbulent water, the abundance of most rotifer taxa was enhanced. Especially the genera Chromogaster, Keratella, Polyarthra, and Trichocerca, increased in abundance. In calm water, chaoborids did not affect the rotifer community. In turbulent water predation by chaoborids was targeted more towards cladocerans
\end{abstract}

Handling editor: Karl E. Havens

J. Horppila $(\bowtie) \cdot$ L. Härkönen · N. Hellén ·

S. Estlander · A. Ojala

Ecosystems and Environment Research Programme,

Faculty of Biological and Environmental Sciences,

University of Helsinki, P.O. Box 65, 00014 Helsinki,

Finland

e-mail: jukka.horppila@helsinki.fi

J. Horppila · A. Ojala

Faculty of Biological and Environmental Sciences, Helsinki Institute of Sustainability Science (HELSUS), Helsinki, Finland

\section{Z. Pekcan-Hekim}

Swedish University of Agricultural Sciences,

Kustlaboratoriet, Skolgatan 6, 74242 Öregrund, Sweden

\section{A. Ojala}

Faculty of Agriculture and Forestry, Institute of Atmospheric and Earth System Research (INAR)/Forest

Sciences, University of Helsinki, Helsinki, Finland
(Bosmina sp.) and predation pressure on rotifers was relaxed. Additionally, reduced competition with cladocerans probably contributed to the increase of rotifer abundance. Turbulence alone had no significant effect on rotifer abundance because their individual size was small compared with the diameter of the turbulent eddies. The study suggested that the effects of turbulence on rotifers is not direct but takes place through changed predator-prey relations, i.e., the effect depends on the abundance of invertebrate predators. In aquatic ecosystems with a high density of chaoborids, increasing turbulence can considerably increase the abundance of rotifers.

Keywords Rotifers - Turbulence · Predation · Invertebrate predators

\section{Introduction}

Small-scale turbulence is an abiotic factor that contributes to the feeding of aquatic animals by affecting encounter rates between predators and prey and thereby influencing ingestion rates of predators (Rothschild \& Osborn, 1988; Marrasé et al., 1990; Härkönen et al., 2014a). The effects of turbulence depend on the size and swimming speed of the organisms. Large and strong swimmers such as adult fish are usually unaffected by turbulence due to their high maneuverability (Kiørboe \& Saiz, 1995). On the 
other hand, very small organisms may also be immune to turbulence (Peters \& Marrasé, 2000; Zhou et al., 2016). The most pronounced effects of turbulence have been described for organisms of intermediate sizes, such as crustacean zooplankton, macroinvertebrates, and larval fish (Rothschild \& Osborn, 1988; MacKenzie et al., 1994; Kiørboe \& Saiz, 1995).

Studies on the effects of turbulence on rotifers, which are usually clearly smaller than crustacean zooplankton and in size range of 100-700 $\mu \mathrm{m}$, have been relatively sparse and conclusions have been variable. Both positive and negative responses of rotifers to increasing turbulence have been reported (Miquelis et al., 1998; Sluss et al., 2008; G.-Tóth et al., 2011; Zhou et al. 2018). Clarification is needed because rotifers can make significant contributions to zooplankton abundance and productivity in numerous lakes (Mackarewicz \& Likens, 1979; Pace \& Orcutt, 1981). Due to their high abundance in some ecosystems, rotifer community grazing rates may match, or even exceed those of some crustaceans both on a daily and annual basis (Bogdan \& Gilbert, 1982). Additionally, rotifers form a substantial food source for many planktivorous organisms, including cladocerans, copepods, chaoborids, and fish larvae (Williamson, 1983; Moore \& Gilbert, 1987; Nagata et al., 2006). Therefore, any disturbance affecting rotifer communities may influence the whole aquatic food web, and turbulence levels in many aquatic ecosystems are probably increasing due to increasing wind speeds and decreasing water levels, and these changes will influence the planktonic communities (Pryor et al., 2005; G.-Tóth et al., 2011).

In an outdoor pond experiment, Härkönen et al. (2014b) showed that intermediate turbulence affected crustacean zooplankton communities via changes in the feeding efficiency and prey selection of predators. The predation pressure exerted by invertebrate predators (larvae of the phantom midge Chaoborus flavicans (Meigen)) on crustacean zooplankton, especially the cladoceran genus Bosmina sp., increased when turbulence was introduced to the system. The study focused on crustacean zooplankton, and for rotifers, only total biomasses were reported. Therefore, in this study, the effects of turbulence on the rotifer community in the experiment were explored in detail. It was expected, that turbulence has only minor effects on rotifer communities due to their small individual size. Additionally, it was hypothesized that inclusion of chaoborids in the system would enhance the abundance of rotifers (e.g., Yan et al., 1991).

\section{Materials and methods}

Experimental set-up

The study was conducted between 23 July and 31 August in summer 2012 in outdoor ponds filled with humic water (area $8.1 \mathrm{~m}^{2}$, volume 32001 , mean depth $40 \mathrm{~cm}$, maximum depth $60 \mathrm{~cm}$ ) in the Evo district $\left(61^{\circ} 13^{\prime} \mathrm{N}, 25^{\circ} 12^{\prime} \mathrm{E}\right)$, southern Finland. The ponds were rectangular, had a sand-gravel bottom covered with a 0.5-1 cm layer of organic debris and had no macrophyte vegetation, but only natural communities of phytoplankton. The experiments included two different predation regimes: no predation (CTRL), and invertebrate predation (IP; 3th and 4th instar larvae of the phantom midge $C$. flavicans) and two different turbulence conditions: no induced turbulence (CALM), and intermediate turbulence (TURB; RMS velocity of $1.4 \mathrm{~cm} \mathrm{~s}^{-1}$, dissipation rate $5.6 \times 10^{-6} \mathrm{~m}^{2} \mathrm{~s}^{-3}$ ). In the CALM-treatments, the natural background RMS velocity was $0.3 \pm 0.1 \mathrm{~cm} \mathrm{~s}^{-1}$ (dissipation rate $4.6 \times 10^{-8} \mathrm{~m}^{-2} \mathrm{~s}^{-3}$ ). In lakes, the dissipation rate in the surface mixed layer during calm conditions often varies between $10^{-9}$ and $10^{-8} \mathrm{~m}^{2} \mathrm{~s}^{-3}$, and can rise to $10^{-6}-10^{-5} \mathrm{~m}^{2} \mathrm{~s}^{-3}$ during wind forcing (Saggio \& Imberger, 1998; MacIntyre et al., 1999). Thus, the turbulence conditions in the experimental ponds corresponded to natural lake circumstances. Based on the dissipation rate and kinematic viscosity of the water (Tennekes \& Lumley, 1972; Zhou et al., 2016), the smallest eddy diameter in our experiment was c. $0.7 \mathrm{~mm}$. Each experiment of the four combinations of turbulence and predation (CALM-CTRL, CALM-IP, TURB-CTRL, TURB-IP) included three replicate ponds. The different treatments and replicates were situated randomly in the experimental pond area. $C$. flavicans larvae were used as they are important predators of rotifer communities and are often abundant in humic lakes common also in lakes in the Evo district (Liljendahl-Nurminen et al., 2003; Wissel et al., 2003).

The ponds were filled with water from the nearby dystrophic River Majajoki (coming from Lake Majajärvi) after filtration through a $50 \mu \mathrm{m}$ net. The watercolor in the ponds was $140 \mathrm{mg} \mathrm{Pt}^{-1}$. Turbulence was generated with computer-controlled 
submersible pumps (Tunze Turbelle nanostream 6055; Tunze Aquarientechnik GmbH, Penzberg, Germany) and measured with an acoustic Doppler velocimeter (ADV, 10-MHz ADVField; Sontek/YSI, San Diego, CA, USA). The natural zooplankton community was collected from the dystrophic Lake Majajärvi, and equal aliquots of zooplankton were added to each pond before the experiments. The zooplankton samples were taken with a $153 \mu \mathrm{m}$ plankton net in the daytime by horizontal hauls in the uppermost $2 \mathrm{~m}$ layer, which prevented chaoborids larvae of being included in the samples. During daytime in Lake Majajärvi (max depth $12 \mathrm{~m}$ ), third and fourth instars of Chaoborus larvae inhabit water layers below $4 \mathrm{~m}$ (Horppila et al., 2018). The relatively large mesh size was chosen for zooplankton collection because Lake Majajärvi is inhabited by the flagellate Gonyostomum semen (Ehrenberg) Diesing, which makes the use of smaller mesh sizes impossible due to clogging (Cronberg et al., 1988; Estlander et al., 2009). Third and fourth instars of Chaoborus larvae were collected from Lake Majajärvi with vertical hauls of a plankton net (mesh size $180 \mu \mathrm{m}$ ). Each experimental pond with IP treatment received 960 larvae, leading to an initial density of 0.3 ind. $1^{-1}$ that corresponds to densities found in numerous lakes (Wissel et al., 2003; Estlander et al., 2009).

Sampling and analyses

The ponds were sampled at 4-d intervals for 5 weeks. Zooplankton samples were taken with a tube sampler (diameter $5.4 \mathrm{~cm}$, length $50 \mathrm{~cm}$ ). From each pond during each sampling, five samples from random places were lifted and combined, resulting in a 61 sample volume per pond. The water was filtered through a $50 \mu \mathrm{m}$ plankton net and the samples were preserved in $4 \%$ formaldehyde. Rotifers were analyzed by inverted microscopy (Olympus CK40; $125 \times$ magnification; Olympus Corporation, Tokyo, Japan), measured for length and identified to species or genus level. The biomasses were calculated from individual lengths, using length-weight regressions (Dumont et al., 1975; Bottrell et al., 1976). Together with chaoborids, the biota of Lake Majajärvi includes also other invertebrate predators preying on rotifers; cyclopoid copepods and the cladoceran Polyphemus pediculus (L.). As the filtration did not exclude these taxa, their abundance in the different treatments was also examined. Because Bosmina is usually the main crustacean prey for chaoborids (Stenson, 1990; Lüning-Krizan, 1997; Liljendahl-Nurminen et al., 2003), results on Bosmina biomass are also shown to explain the turbulence-mediated variations in the feeding preferences of chaoborids.

Water temperature, dissolved oxygen and $\mathrm{pH}$ in each pool on each sampling date were measured with a YSI 6600V2 sonde (YSI Inc. Yellow Springs, OH, USA). Total phosphorus and total nitrogen samples were taken with the tube sampler and analyzed with Lachat Autoanalyzer [Quickchem Series 8000, Lachat Instruments, (Hach Company)] according to Koroleff (1979). Chlorophyll $a$ samples were taken with a tube sampler, filtered with Whatman GF/C filters, and analyzed spectrophotometrically (Shimadzu UV-260, UV-Visible Recording Spectrophotometer, Shimadzu Corporation, Tokyo, Japan) after extraction with ethanol according (Finnish Standard Association, 1993).

\section{Statistical analyses}

The effect of the different treatments on the density and biomass of various rotifer taxa were analyzed with analysis of variance for repeated measurements (ANOVAR), accounting for the temporal autocorrelation of the sequential samples. The data were $\ln (x+1)$ transformed before the analyses. The analyses were conducted on genus level on those rotifer genera exceeding the average density of 5 ind. $1^{-1}$ in at least one treatment. Other rotifer taxa were grouped, except Asplanchna spp. Asplanchna species are predaceous rotifers and can regulate other rotifer species (Gilbert, 1980; Conde-Porcuna \& DeClerck, 1998). Therefore its abundance in the different treatments was tested separately. Additionally, because variable responses of different species within genera might be masked if only genera were analyzed, the density and biomass fluctuations of six dominant species [Chromogaster ovalis (Bergendal), Conochilus unicornis (Rousselet), Keratella cochlearis (Gosse), Polyarthra remata Skorikov, Trichocerca porcellus (Gosse), Asplanchna priodonta (Gosse)] were analyzed with ANOVAR. Moreover, the between-treatment differences in the biomass of cyclopoids, $P$. pediculus, and Bosmina sp. were studied with ANOVAR. Pairwise comparisons were performed with Bonferroni t-tests and tests with 
$P$ values $<0.05$ were judged significant. The possible difference in the initial rotifer biomass between treatments was analyzed with analysis of variance (ANOVA, $\ln (x+1)$-transformed data). Differences in the average individual length of rotifers were analyzed with ANOVA (all taxa combined and different taxa separately). Additionally, as rotifer abundance often increases with increasing chlorophyll $a$ concentration via increasing food abundance (Nagata et al., 2006), the variations in chlorophyll $a$ concentration were analyzed with ANOVAR.

\section{Results}

The physical and chemical water quality variations between the treatments were very small. Water temperature fluctuated between 18 and $23^{\circ} \mathrm{C}$, and between-treatment differences remained below $0.5^{\circ} \mathrm{C}$. The concentration of dissolved oxygen was between 8 and $9 \mathrm{mg} \mathrm{l}^{-1}$ and water $\mathrm{pH}$ between 6.8 and 6.9 in all the treatments. The average total phosphorus concentration varied between 16 and $21 \mu \mathrm{g} \mathrm{l}^{-1}$ and total nitrogen concentration between 800 and $850 \mu \mathrm{g}^{-1}$. Chlorophyll $a$ concentration fluctuated between 13 and $19 \mu \mathrm{g} \mathrm{l}^{-1}$, with no differences between the treatments $(P=0.244)$.

Altogether 27 rotifer species were discovered from the ponds during the study period. In the initial densities or biomasses of the different rotifer taxa, no between-treatment differences were observed $(P>0.05)$, except in Polyarthra, which was more abundant in the TURB treatments than in CALMtreatments (density $P=0.0256$, biomass $P=0.0497$ ). The total density of rotifers varied between 200 and 500 ind. $1^{-1}$ at the beginning of the experiment, decreased during July in all treatments and remained below 100 ind. $1^{-1}$ until the end of the study (Fig. 1). The total density in TURB-IP (average 131.6 ind. $1^{-1}$ ) was significantly higher than in TURB-CTRL (106.5 ind. $1^{-1}$ ) and in CALM-IP (64.2 ind. $1^{-1}$ ) (Fig. 1, Table 1). The total biomass of rotifers was 5-15 $\mu \mathrm{g} \mathrm{C}^{-1}$ at the beginning of the experiments and dropped below $2 \mu \mathrm{g} \mathrm{C}^{-1}$ during the study (Fig. 2). No significant differences in total biomass of rotifers were observed between treatments (Table 2). In CALM-IP, a biomass peak of $15 \mu \mathrm{g} \mathrm{C}$ $1^{-1}$ was detected on 30 July (Fig. 2). It was caused by a temporary increase in abundance of the large-sized
Total density

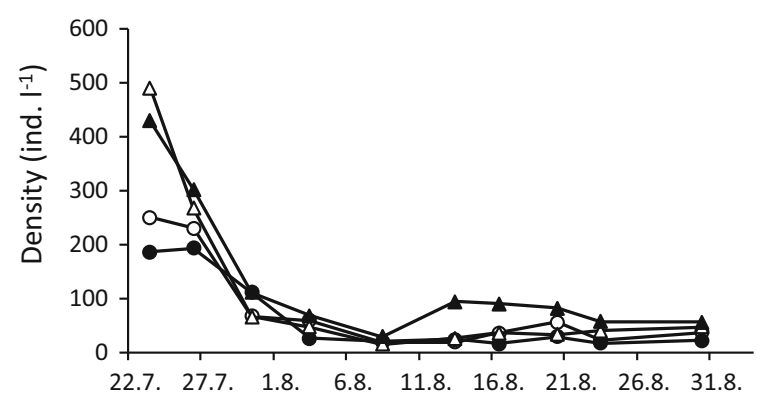

Total biomass

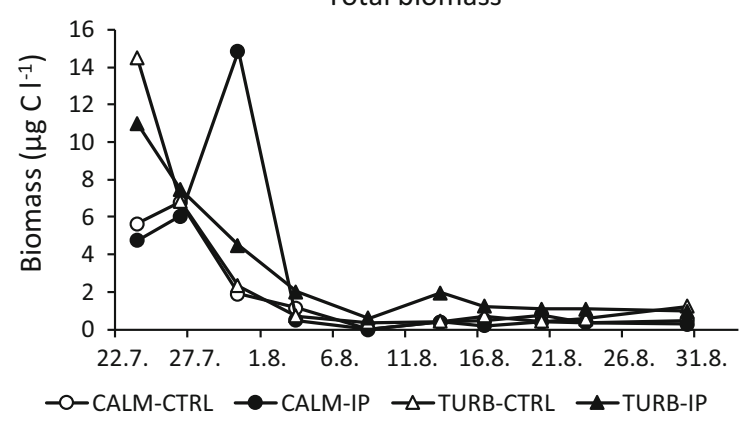

Fig. 1 Total rotifer density and biomass during the experiment in the different treatments

\section{Asplanchna priodonta and Asplanchna herricki (Guerne).}

The most abundant rotifer genera in all treatments during the study period both regarding density and biomass were Keratella (mainly K. cochlearis), Synchaeta spp., Polyarthra (P. remata, P. vulgaris Carlin, $P$. euryptera (Wierzejski)), and Trichocerca (T. porcellus, T. cylindrica Imhof). Synchaeta dominated especially during the first week of the experiment with a density of 100-250 ind. $1^{-1}$ (biomass 3-7 $\mu \mathrm{g} \mathrm{C} 1^{-1}$ ) (Figs. 2, 3). In August, Synchaeta was almost absent while the density Polyarthra and Trichocerca varied mostly between 2 and 30 ind. $1^{-1}$ (biomass 0.05-2 $\mu \mathrm{g} \mathrm{C}^{-1}$ ). Towards the end of the experiment, especially the abundance of Conochilus (mainly $C$. unicornis), and Chromogaster ovalis increased (Figs. 2, 3).

Rotifers were not affected by turbulence alone (Tables 1,2). Introduction of chaoborids into the calm water had no effect either, as no differences between CALM-CTRL and CALM-IP treatments were detected in density or biomass. In turbulent water, however, chaoborids affected the rotifer community. In TURB-IP, the density of all studied genera was 
Table 1 Pairwise, between-treatment comparisons (ANOVAR, Bonferroni $t$-tests) for the differences in the total density and density of the dominant rotifer genera and dominant species (Chromogaster ovalis, Conochilus unicornis, Keratella cochlearis, Polyarthra remata, Trichocerca porcellus) under calm (CALM) and turbulent (TURB) water

\begin{tabular}{|c|c|c|c|c|c|c|c|c|}
\hline Treatment & Total & Chromogaster & Conochilus & Keratella. & Polyarthra & Synchatea & Tricocherca & Asplanchna \\
\hline $\begin{array}{l}\text { CALM-CTRL versus } \\
\text { TURB-CTRL }\end{array}$ & - & - & - & - & - & - & - & - \\
\hline $\begin{array}{l}\text { CALM-CTRL versus } \\
\text { CALM-IP }\end{array}$ & - & - & - & - & - & - & - & - \\
\hline $\begin{array}{l}\text { TURB-CTRL versus } \\
\text { TURB-IP }\end{array}$ & $* *$ & $*$ & - & $*$ & $*$ & - & $* *$ & - \\
\hline $\begin{array}{l}\text { CALM-IP versus TURB- } \\
\text { IP }\end{array}$ & $* *$ & $* *$ & $* *$ & $* *$ & $* *$ & $*$ & $* *$ & - \\
\hline
\end{tabular}

Predator treatments were: CTRL control, no added predators; IP invertebrate predators (Chaoborus flavicans)

$* * P<0.01, * P<0.05,-$ no significant difference

Chromogaster

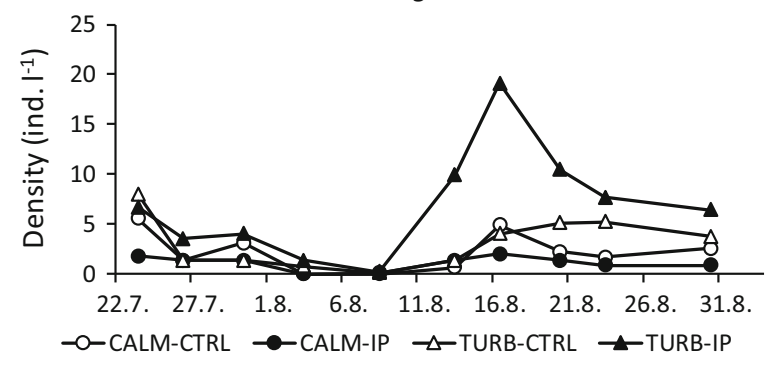

Conochilus

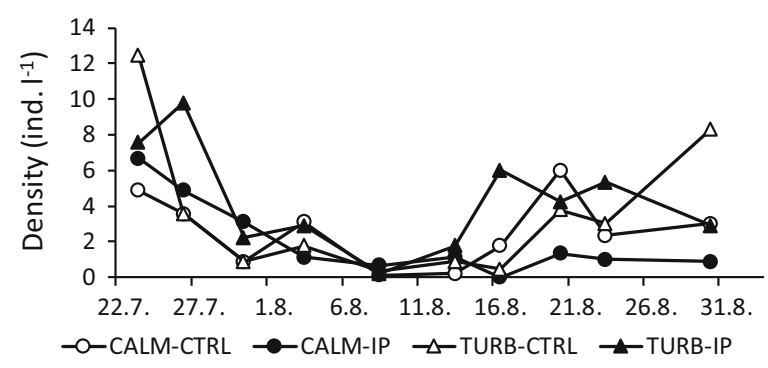

Keratella

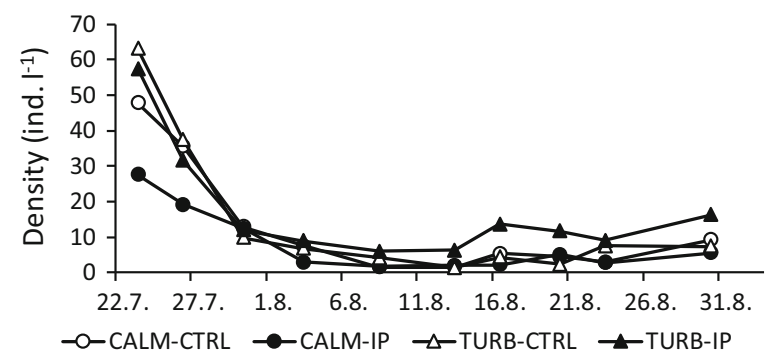

Polyarthra

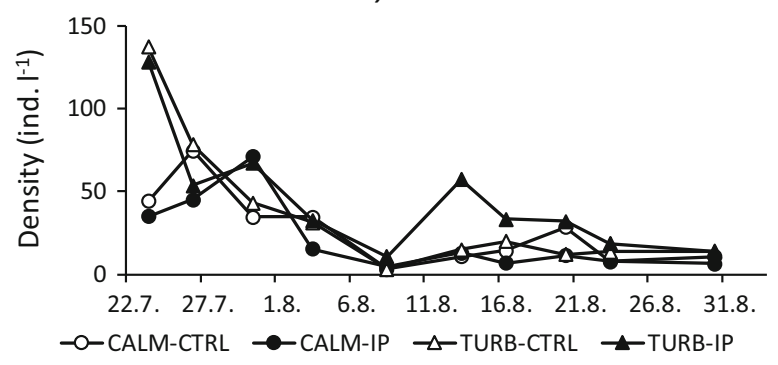

Synchaeta

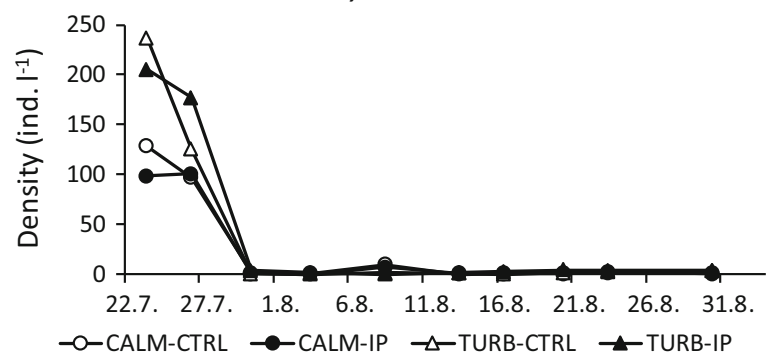

Trichocerca

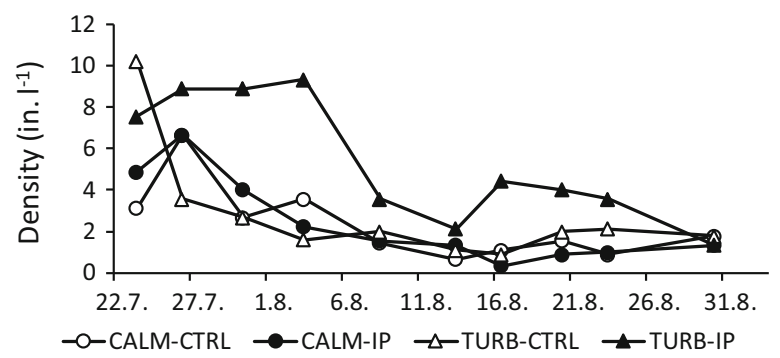

Fig. 2 Density of different rotifer genera during the experiment in the different treatments 


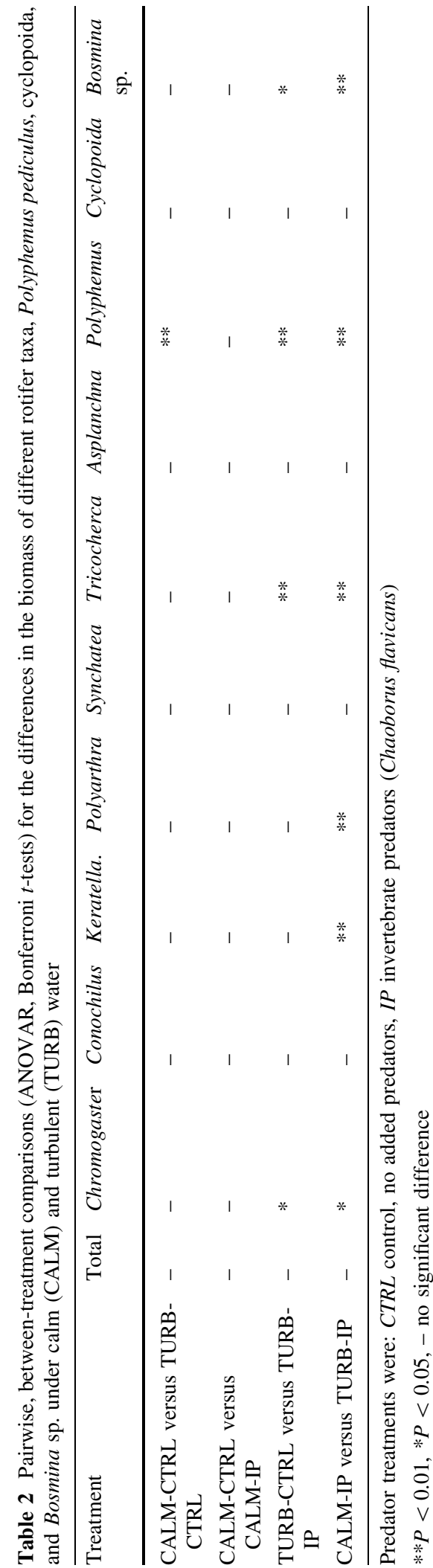

higher than in CALM-IP (Table 1). For most taxa, the density in TURB-IP also exceeded their density in TURB-CTRL. In biomass, fewer significant differences were detected, but the biomass of Chromogaster, Keratella, Polyarthra, and Trichocerca was significantly higher in TURB-IP than in CALM-IP (Table 2). Trichocerca and Chromogaster were also more abundant in TURB-IP than in TURB-CTRL. In the statistical analyses on the dominant species, fewer significant differences were found than at the genus level, but the most significant differences were again found between TURB-IP and CALM-IP and between TURB-CTRL and TURB-IP (Table 3).

The average body length of rotifers varied mostly between $110 \mu \mathrm{m}$ and $140 \mu \mathrm{m}$ (Table 4). When all sampling days were pooled, the average individual size was $125.4 \mu \mathrm{m}$ in CALM-CTRL, $132.9 \mu \mathrm{m}$ in CALM-IP, $132.3 \mu \mathrm{m}$ in TURB-CTRL and $135.3 \mu \mathrm{m}$ in TURB-IP. When the large-sized Asplanchna were excluded, the average sizes were 120.1, 123.4, 126.5 and $129.1 \mu \mathrm{m}$, respectively. In all treatments, the average individual body size of rotifers decreased during the experiment (Table 4). No differences in individual size were detected in any of the genera $(P>0.05$ in all comparisons between treatments) (Fig. 4). Thus, turbulence had no effect on the individual size of rotifers. The minimum individual size of rotifers varied mostly between $30 \mu \mathrm{m}$ and $80 \mu \mathrm{m}$, and the maximum individual size between $250 \mu \mathrm{m}$ and $800 \mu \mathrm{m}$ (Table 4).

The biomass of cyclopoid copepods (mainly Mesocyclops spp.) varied mostly between 2 and $10 \mu \mathrm{g} \mathrm{C}^{-1}$ (1-10 ind. $1^{-1}$ ) during the first week of the experiment and decreased after that (Fig. 5). No differences between the treatments were observed (Tables 1, 2). For Polyphemus, both turbulence and invertebrate predation affected. In TURB-CTRL, the density (max. 26 ind. $1^{-1}$ ) and biomass (max. $15 \mu \mathrm{g} \mathrm{C}^{-1}$ ) were significantly lower than in CALM-CRTL (max. 47 ind. $1^{-1}, \quad 30 \mu \mathrm{g} \mathrm{C}^{-1}$ ) (Fig. 5, Tables 1, 2). Additionally, in TURB-IP, Polyphemus was less abundant than in TURB-CTRL and CALM-IP. The biomass of Bosmina sp. was lower in TURB-IP than in TURB-CTRL or in CALM-IP (Table 2). 

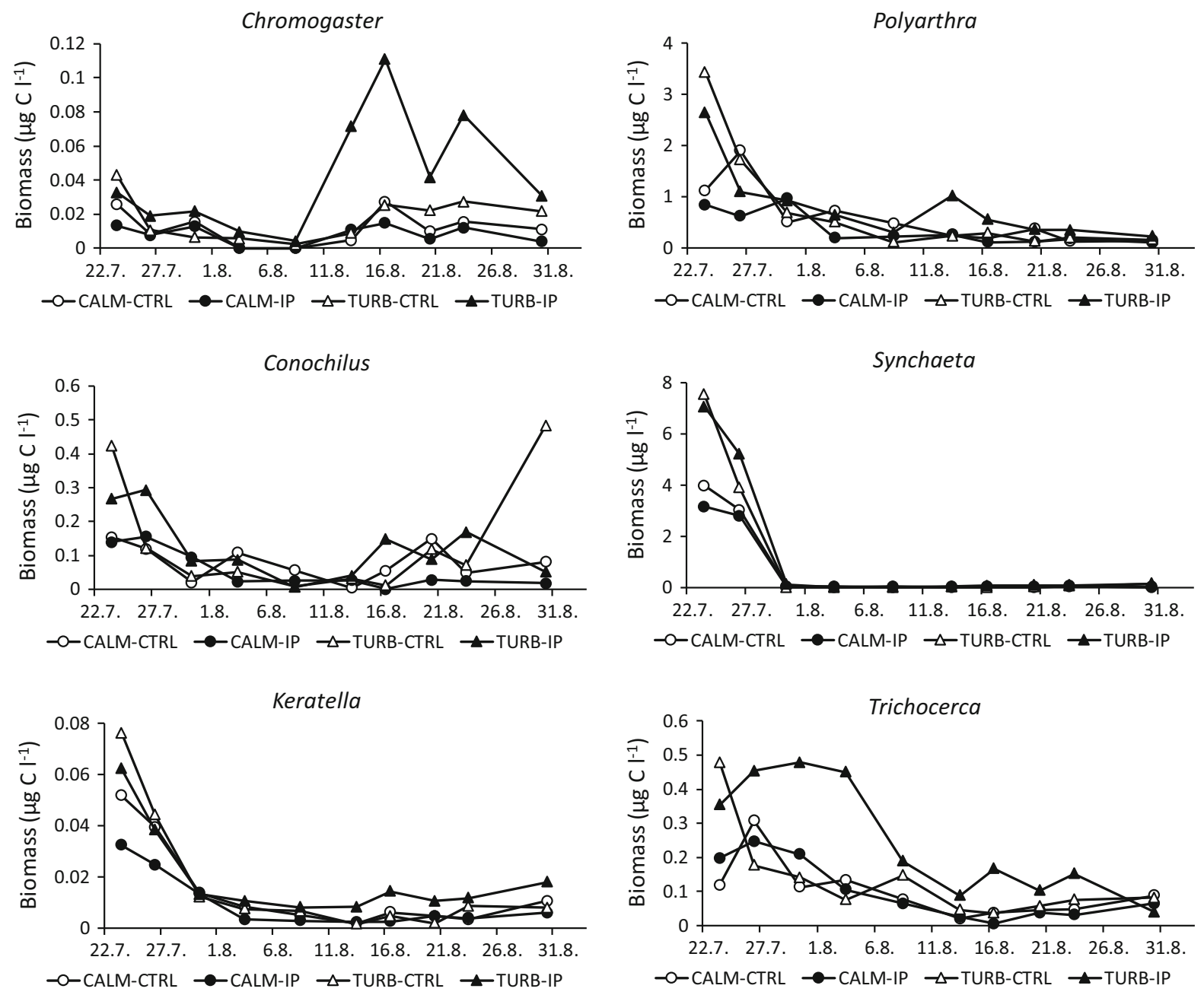

Fig. 3 Biomass of different rotifer genera during the experiment in the different treatments

\section{Discussion}

Both positive and negative responses of rotifers to increasing turbulence have been previously reported (Miquelis et al., 1998; Sluss et al., 2008; G.-Tóth et al., 2011). The present study suggested that intermediate turbulence alone does not have a direct influence on rotifers. This was expected because the effect of turbulence on planktonic organisms depends on the size of the organisms in relation to the size of the turbulent eddies. Especially organisms larger than the diameter of the smallest eddies may be directly affected by turbulent forces (Peters \& Marrasé, 2000; Zhou et al., 2016). In the rotifer community of the experimental ponds, Asplanchna was the only taxon, where the individual size occasionally reached the size of the smallest eddies. The individual size of all other taxa was considerably lower explaining why the direct effects of turbulence on rotifers were weak. The size range of rotifers confirmed that the large mesh size used in plankton sampling did not bias the community structure because the minimum size of all rotifer taxa was considerably beyond $100 \mu \mathrm{m}$. This was explained by reproduction and by rotifers introduced from River Majajoki with water used to fill the ponds. The blocking effect of Gonyostomum could also decrease the realized mesh size of the $153 \mu \mathrm{m}$ net. The species composition and diversity of the rotifer communities in the ponds were typical of humic lakes in the temperate zone (Havens, 1991; Sarvala et al., 1999). The overall decrease of rotifers in all treatments during the experiment was due to natural succession. 


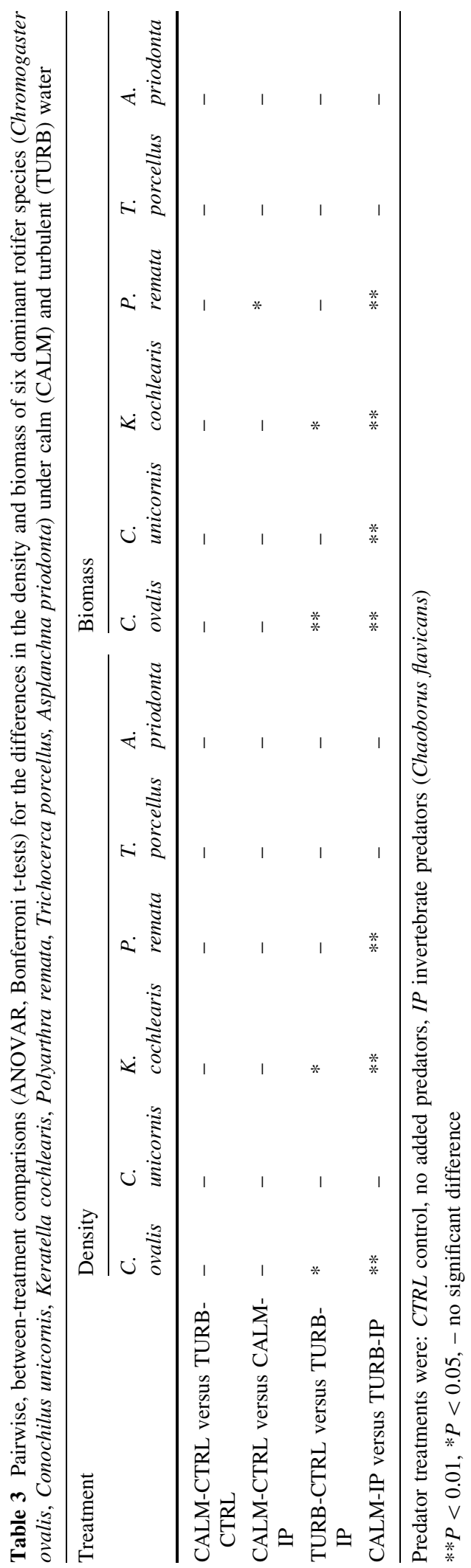

In many lakes, including those in the Evo area, the abundance of rotifers decreases in late summer (Haberman, 1983; Salonen et al., 1991; Habidja et al., 1993).

The experiment demonstrated on the other hand that indirect, predation-mediated effects of turbulence on rotifer communities could be considerable. In treatments, where chaoborids were included, turbulence resulted in the increased abundance of most rotifer taxa. This was most likely a consequence of increased predation by chaoborids on crustacean zooplankton. Predators can affect their prey populations also through non-consumptive effects via influence on reproduction (Heuschele et al., 2014). However, no effect of chaoborids on the abundances of cladoceran embryos and copepod nauplii, their ratios to adult crustaceans (Härkönen et al., 2014b), or in the size structure of the rotifer communities was detected during the experiment. Thus, predation of chaoborids on crustacean zooplankton and its indirect effect on rotifers was the explanation for the observed increase of rotifers in the TURB-IP treatment. Turbulence enhanced the predation by chaoborids on cladocerans and the biomass of the preferred cladoceran prey, Bosmina sp. decreased in TURB-IP compared with CALM-IP. Accordingly, previous studies have shown that rotifers can dominate lake zooplankton when the abundance of chaoborids is high because chaoborid predation is concentrated on crustaceans (Hanazato \& Yasuno, 1989; Havens, 1991; Yan et al., 1991). Larvae of C. flavicans are ambush predators that do not actively search for prey, but attack prey entering their strike area (Swift \& Fedorenko, 1975). Therefore, moderate turbulence such as used in the present experiment can enhance their prey capture rate (MacKenzie \& Kiørboe, 1995; Härkönen et al., 2014b), which is reflected as an increased predation rate especially on their preferred prey items.

The increased chaoborid predation on cladocerans could promote the increase of rotifers by two mechanisms. Firstly, predation on rotifers was relaxed. This had a strong effect on the rotifer community because most dominant rotifer taxa in the ponds belong to the diets of chaoborids (Elser et al., 1987; Moore \& Gilbert, 1987; Vanni, 1988; Liljendahl-Nurminen et al., 2003). Secondly, the reduction of cladocerans increased rotifer abundance through reduced competition between cladocerans and rotifers (MacIsaac \& 
Table 4 The average, minimum and maximum individual size of rotifers in the different treatments during the experiment

\begin{tabular}{|c|c|c|c|c|c|c|c|c|c|c|c|c|}
\hline & \multicolumn{3}{|c|}{ CALM-CTRL } & \multicolumn{3}{|c|}{ CALM-IP } & \multicolumn{3}{|c|}{ TURB-CTRL } & \multicolumn{3}{|c|}{ TURB-IP } \\
\hline & Aver. & Min. & Max. & Aver. & Min. & Max. & Aver. & Min. & Max. & Aver. & Min. & Max. \\
\hline 23 July & 129.8 & 58.2 & 300.7 & 134.4 & 67.9 & 310.4 & 132.1 & 58.2 & 679.0 & 146.3 & 67.9 & 368.6 \\
\hline 26 July & 134.2 & 67.9 & 582.0 & 132.1 & 67.9 & 630.5 & 137.1 & 67.9 & 407.4 & 137.4 & 77.6 & 300.7 \\
\hline 30 July & 119.0 & 67.9 & 611.1 & 130.9 & 67.9 & 776.0 & 126.8 & 67.9 & 698.4 & 127.4 & 58.2 & 873.0 \\
\hline 3 Aug. & 119.2 & 67.9 & 252.2 & 125.2 & 67.9 & 300.7 & 128.7 & 29.1 & 252.2 & 126.9 & 67.9 & 582.0 \\
\hline 8. Aug. & 95.1 & 58.2 & 310.4 & 99.0 & 77.6 & 446.2 & 125.8 & 67.9 & 300.7 & 129.1 & 38.8 & 252.2 \\
\hline 13 Aug. & 112.3 & 67.9 & 271.6 & 104.4 & 67.9 & 155.2 & 109.3 & 67.9 & 223.1 & 126.7 & 38.8 & 281.3 \\
\hline 16 Aug. & 116.6 & 58.2 & 223.1 & 110.4 & 29.1 & 194.0 & 112.0 & 67.9 & 417.1 & 121.5 & 67.9 & 291.0 \\
\hline 20 Aug. & 113.9 & 58.2 & 261.9 & 121.0 & 58.2 & 300.7 & 114.0 & 38.8 & 291.0 & 125.0 & 48.5 & 388.0 \\
\hline 23 Aug. & 124.5 & 38.8 & 329.8 & 126.2 & 38.8 & 397.7 & 137.4 & 38.8 & 300.7 & 134.1 & 29.1 & 291.0 \\
\hline 30 Aug. & 118.8 & 48.5 & 300.7 & 121.9 & 67.9 & 310.4 & 130.5 & 58.2 & 446.2 & 112.5 & 58.2 & 436.5 \\
\hline
\end{tabular}
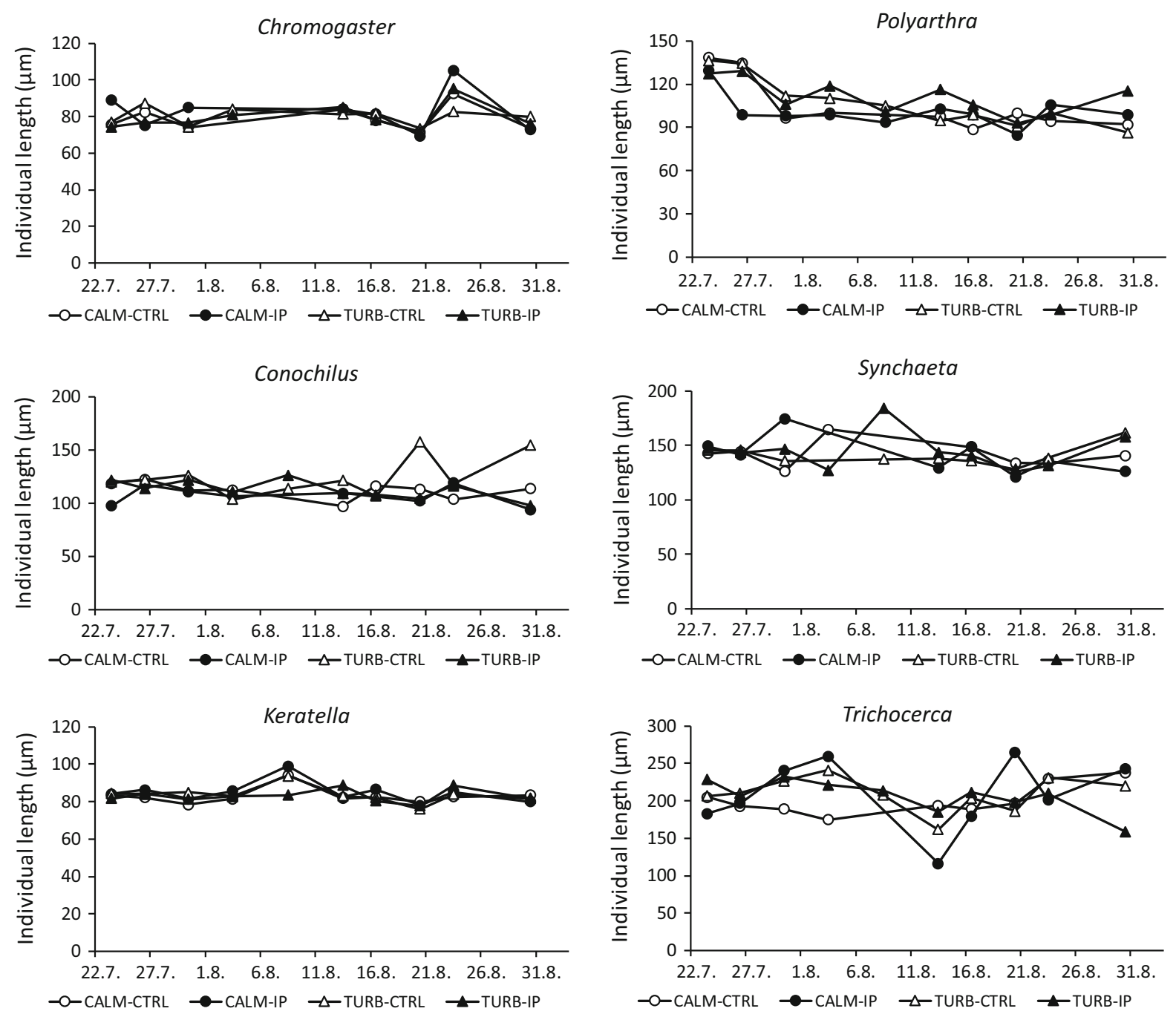

Fig. 4 The average individual size of the dominant rotifer genera in the different treatments 

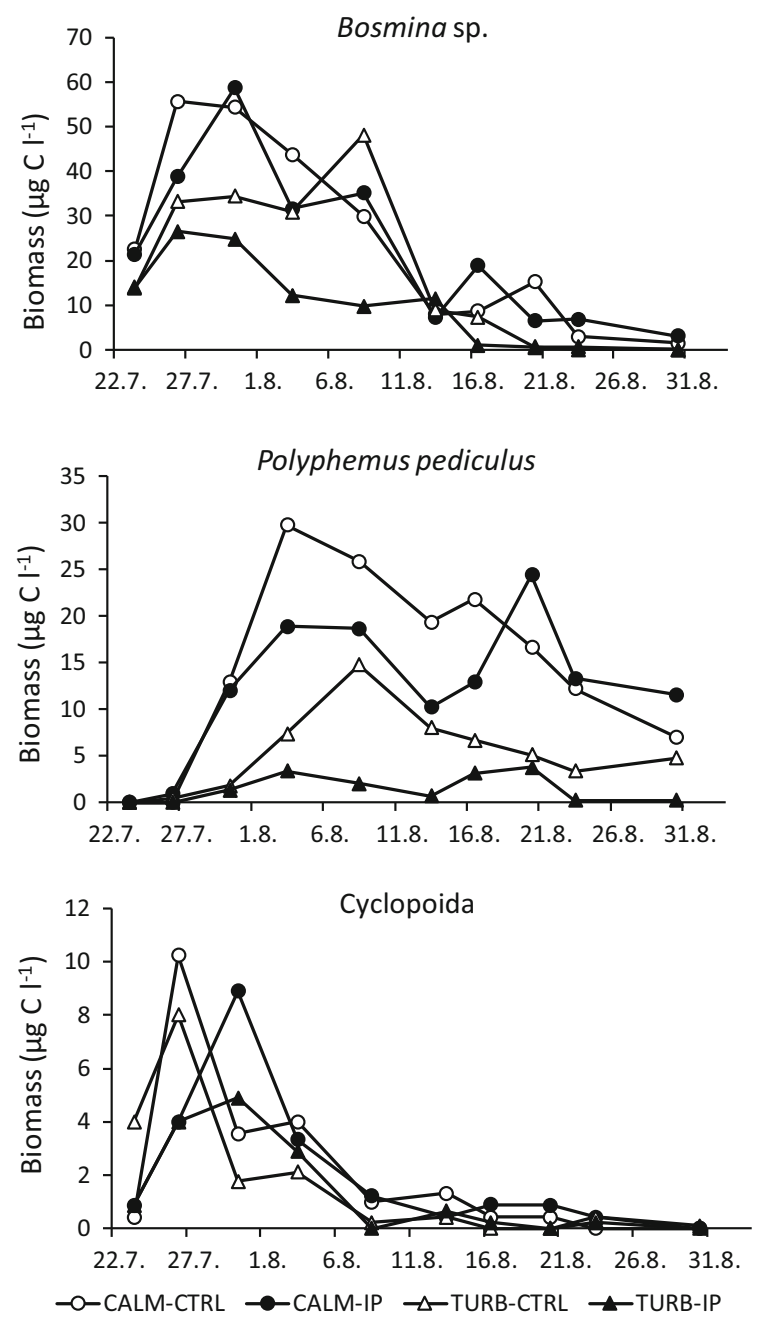

Fig. 5 Biomass of Bosmina sp., Polyphemus pediculus, and cyclopoid copepods during the experiment

Gilbert, 1989; Lampert \& Rothhaupt, 1991). Rotifer density was enhanced more strongly than their biomass, which was due to a negative dependence of individual size and density, a common phenomenon in rotifer and other zooplankton communities (Stemberger \& Gilbert, 1985; Pace, 1986; Cyr et al., 1997).

Another explanation for the increase of rotifers in turbulent conditions could be the decreased abundance of the predatory cladoceran Polyphemus in TURB ponds. Polyphemus feeds for instance on Keratella, Polyarthra, and Conochilus (Packard, 2001) and a reduction in its abundance could be reflected in rotifers. This explanation can, however, be rejected, because Polyphemus was also depressed in TURBCTRL, which showed no difference in rotifer abundance compared with CALM-CTRL with high Polyphemus biomass. The decrease of Polyphemus in turbulent conditions could be expected, since it is vulnerable to environmental disturbances and usually exists only in very sheltered habitats (Butorina, 1986). Cyclopoid copepods can regulate rotifers (Lapesa et al., 2002; Sluss et al., 2008), but no betweentreatment differences in cyclopoid abundance were observed. Turbulence can enhance the prey encounter rate of cyclopoids copepods (Kiørboe \& Saiz, 1995), but the minor differences between TURB-CTRL and CALM-CTRL confirmed that copepods did not regulate rotifers even in the turbulent treatments.

A factor that could also potentially affect the abundance of rotifers in the experiment was the impact of turbulence on rotifers attached on substrata. Most of the dominant rotifer taxa in the experiment can be periphytic (Duggan, 2001). Compared with the calm ponds, water movements in the turbulent ponds probably snatched rotifers from the periphytic mode on bottom substratum to the limnetic mode (Horner \& Welch, 1981; Schmid-Araya, 1993). This was not, however, a major factor behind between-treatment differences in rotifer abundance, because no differences between TURB-CTRL and CALM-CTRL were observed. The impact of turbulence on periphytic rotifers probably affected the results in the first sampling day, when all dominant taxa were somewhat more abundant in the turbulent than in the calm ponds. The effect of turbulence on the attachment of periphyton to substrata was not an experimental artifact, but the phenomenon is also present in natural shallow aquatic systems (Weisner et al., 1997).

The experiment suggested that the previously very variable results on the effects of turbulence on rotifers may have depended on the differences in the predation regimes between the studied systems. For instance, (G.-Tóth et al., 2011) reported negative effects of increased turbulence on Keratella, while Sluss et al. (2008) suggested that Keratella could be favored by turbulence. The former study was conducted in field conditions including invertebrate predators and the latter with an experimental setup lacking large invertebrate predators. The present study suggested that the effects of turbulence on rotifers can depend on the abundance of their invertebrate predators. This study was conducted in humic water, but invertebrate predators are important predators also in other types of waters. Chaoborus flavicans can for instance form 
high densities also in many eutrophic, clay-turbid, as well as in acidified waters, in both fishless and fish-rich conditions (Yan et al., 1991; Xie et al., 1998; Dawidowicz et al., 2002; Liljendahl-Nurminen et al., 2003). Due to their ability to burrow into the sediment, chaoborids may prevail both in shallow and in deep stratifying lakes (Parma, 1971; Liljendahl-Nurminen et al., 2002). Bosminids are an important group in the herbivorous zooplankton of many types of lakes (Lieder, 1983; Beaver et al., 2018). Thus, the present results on the indirect effect of turbulence on rotifers via relaxed chaoborid predation are probably applicable to a large number of water bodies. The study also has implications for the future. Because climate models have predicted increasing wind velocities and wind is a major force inducing turbulence in lake ecosystems (Imboden \& Wüest, 1995; Giorgi et al., 2004) climate change can lead to an increasing abundance of rotifers in lakes with abundant populations of invertebrate predators.

Acknowledgements Open access funding provided by University of Helsinki including Helsinki University Central Hospital. The study was conducted in the facilities of Evo Fisheries Research Station and financially supported by the Academy of Finland (project 131579). Jukka Ruuhijärvi, Martti Rask, Teemu Lakka, Riikka Pesonen, Petrina Köngäs, Lauri Happo, Marianna Joensuu, and Raija Mastonen assisted with the construction of the setup, running the experiments and analyzing the samples.

Open Access This article is distributed under the terms of the Creative Commons Attribution 4.0 International License (http:// creativecommons.org/licenses/by/4.0/), which permits unrestricted use, distribution, and reproduction in any medium, provided you give appropriate credit to the original author(s) and the source, provide a link to the Creative Commons license, and indicate if changes were made.

\section{References}

Beaver, J. R., T. R. Renicker, C. E. Tausz \& B. T. Vitanye, 2018. Distribution of six taxa in the family Bosminidae Baird (Crustacea: Branchiopoda: Anomopoda) in the plankton of lakes and reservoirs within the continental United States, including expanded range of the invasive cladoceran Bosmina (Eubosmina) coregoni Baird. Zootaxa 4407: 506-520.

Bogdan, K. G. \& J. J. Gilbert, 1982. Seasonal patterns of feeding by natural populations of Keratella, Polyarthra, and Bosmina: clearance rates, selectivities, and contributions to community grazing. Limnology and Oceanography 27: 918-934.
Bottrell, H. H., A. Duncan, Z. Gliwicz, E. Grykierek, A. Herzig, A. Hillbricht-Ilkowska, H. Kurasawa, P. Larsson \& T. Weglenska, 1976. A review of some problems in zooplankton production studies. Norwegian Journal of Zoology 24: 419-456.

Butorina, L. G., 1986. On the problem of aggregations of planktonic crustaceans (Polyphemus pediculus (L.), Cladocera). Archiv für Hydrobiologie 105: 355-386.

Conde-Porcuna, J. M. \& S. DeClerck, 1998. Regulation of rotifer species by invertebrate predators in a hypertrophic lake: selective predation on egg-bearing females and induction of morphological defences. Journal of Plankton Research 20: 605-618.

Cronberg, C., G. Lindmark \& S. Björk, 1988. Mass development of the flagellate Gonyostomum semen (Rapidophyta) in Swedish forest lakes - an effect of acidification? Hydrobiologia 161: 217-236.

Cyr, H., J. A. Downing \& R. H. Peters, 1997. Density-body size relationships in local aquatic communities. Oikos 79: 333-346.

Dawidowicz, P., A. Prejs, A. Engelmayer, A. Martyniak, J. Kozlowski, L. Kufel \& M. Paradowskas, 2002. Hypolimnetic anoxia hampers top-down food-web manipulation in a eutrophic lake. Freshwater Biology 47: 2401-2409.

Duggan, I. C., 2001. The ecology of periphytic rotifers. Hydrobiologia 446(447): 139-148.

Dumont, H. J., I. van der Velde \& S. Dumont, 1975. The dry weight estimate of biomass in a selection of Cladocera, Copepoda and Rotifera from the plankton, periphyton and benthos of continental waters. Oecologia 19: 75-97.

Elser, M. M., C. N. Von Ende, P. Sorrano \& S. R. Carpenter, 1987. Chaoborus populations: a response to food web manipulation and potential effects on zooplankton communities. Canadian Journal of Zoology 65: 2846-2852.

Estlander, S., L. Nurminen, M. Vinni \& J. Horppila, 2009. Seasonal fluctuations in macrophyte cover and water transparency of four brown-water lakes - implications for crustacean zooplankton in littoral and pelagic habitats. Hydrobiologia 620: 109-120.

Finnish Standard Association, 1993. Determination of chlorophyll $a$ in water. Extraction with ethanol. Standard 5772. Finnish Standard Association, Helsinki.

G.-Tóth, L., L. Parpala, C. Balogh, I. Tàtrai \& E. Baranyai, 2011. Zooplankton community response to enhanced turbulence generated by water-level decrease in Lake Balaton, the largest shallow lake in Central Europé. Limnology and Oceanography 56: 2211-2222.

Gilbert, J. J., 1980. Observations on the susceptibility of some protists and rotifers to predation by Asplanchna girodi. Hydrobiologia 73: 87-91.

Giorgi, F., X. Bi \& J. Pal, 2004. Mean interannual variability and trends in a regional climate change experiment over Europe. II: climate Change Scenarios (2071-2100). Climate Dynamics. 7-8: 839-858.

Haberman, J., 1983. Comparative analysis of planktonic rotifer biomass in large Estonian lakes. Hydrobiologia 104: 293-296.

Habidja, I., B. Primc-Habidja, R. Erben \& I. Belinić, 1993. Trophic role of rotifers in the plankton of Lake Kozjak (Plitvice Lakes). Hydrobiologia 257: 101-106. 
Hanazato, T. \& M. Yasuno, 1989. Zooplankton community structure driven by vertebrate and invertebrate predators. Oecologia 81: 450-458.

Härkönen, L., Z. Pekcan-Hekim, N. Hellén \& J. Horppila, 2014a. Feeding efficiency of Chaoborus flavicans (Insecta, Diptera) under turbulent conditions. Hydrobiologia 722: 9-17.

Härkönen, L., Z. Pekcan-Hekim, N. Hellén, A. Ojala \& J. Horppila, 2014b. Combined effects of turbulence and different predation regimes on zooplankton in highly colored water - implications for environmental change in lakes. PLoS ONE 9(11): e111942.

Havens, K. E., 1991. Summer zooplankton dynamics in the limnetic and littoral zones of a humic acid lake. Hydrobiologia 215: 21-29. '.

Heuschele, J., S. Ceballos, C. M. Andersen Borg, O. Bjærke, S. Isari, L. Lasley-Rasher, E. Lindehoff, A. Souissi, S. Souissi \& J. Titelman, 2014. Noon-consumptive effects of predator presence on copepod reproduction: insights from a mesocosm experiment. Marine Biology 161: 1653-1666.

Horner, R. R. \& E. B. Welch, 1981. Stream periphyton development in relation to current velocity and nutrients. Canadian Journal of Fisheries and Aquatic Sciences 38: 449-457.

Horppila, J., A. Liljendahl, S. Estlander \& L. Nurminen, 2018. The role of visual and physiological refuges in humic lakes: effects of oxygen, light quantity and spectral composition on daytime depth of chaoborids. International Review of Hydrobiology 103: 63-70.

Imboden, D. M. \& A. Wüest, 1995. Mixing mechanisms in lakes. In Lerman, A., D. Imboden \& J. Gat (eds), Physics and chemistry of lakes, 2nd ed. Springer-Verlag, Berlin: 83-138.

Kiørboe, T. \& E. Saiz, 1995. Planktivorous feeding in calm and turbulent environments, with emphasis on copepods. Marine Ecology Progress Series 122: 135-145.

Koroleff, F., 1979. Methods for the chemical analysis for seawater. Meri 7: 1-60.

Lampert, W. \& K. O. Rothhaupt, 1991. Alternating dynamics of rotifers and Daphnia magna in a shallow lake. Archiv für Hydrobiologie 120: 447-456.

Lapesa, S., T. W. Snell, D. M. Fields \& M. Serra, 2002. Predatory interactions between a cyclopoid copepod and three sibling rotifer species. Freshwater Biology 47: 1685-1695.

Lieder, U., 1983. Revision of the genus Bosmina Baird, 1845 (Crustacea, Cladocera). Internationale Revue der gesamten Hydrobiologie und Hydrographie 68: 121-139.

Liljendahl-Nurminen, A., J. Horppila, P. Eloranta, T. Malinen \& L. Uusitalo, 2002. The seasonal dynamics and distribution of Chaoborus flavicans in adjacent lake basins of different morphometry and degree of eutrophication. Freshwater Biology 47: 1283-1295.

Liljendahl-Nurminen, A., J. Horppila, T. Malinen, P. Eloranta, M. Vinni, E. Alajärvi \& S. Valtonen, 2003. The supremacy of invertebrate predators over planktivorous fish - factors behind the unconventional seasonal dynamics of cladocerans in Lake Hiidenvesi. Archiv für Hydrobiologie 158: $75-96$.

Lüning-Krizan, J., 1997. Selective feeding of third and fourthinstar larvae of Chaoborus flavicans in the field. Archiv für Hydrobiologie 140: 347-365.
MacIntyre, S., K. M. Flynn, R. Jellison \& J. R. Romero, 1999. Boundary mixing and nutrient fluxes in Mono Lake, California. Limnology and Oceanography 44: 512-529.

MacIsaac, H. J. \& J. J. Gilbert, 1989. Competition between rotifers and cladocerans of different body sizes. Oecologia 81: 295-301.

Mackarewicz, J. C. \& G. E. Likens, 1979. Structure and function of the zooplankton community of Mirror Lake, New Hampshire. Ecological Monographs 49: 109-127.

MacKenzie, B. R., T. J. Miller, S. Cyr \& W. C. Leggett, 1994. Evidence for a dome-shaped relationship between turbulence and larval fish ingestion rates. Limnology and Oceanography 39: 1790-1799.

MacKenzie, B. R. \& T. Kiørboe, 1995. Encounter rates and swimming behavior of pause-travel and cruise larval fish predators in calm and turbulent laboratory environments. Limnology and Oceanography 40: 1278-1289.

Marrasé, C., J. H. Costello, T. Granata \& J. R. Strickler, 1990. Grazing in a turbulent environment: energy dissipation, encounter rates, and efficacy of feeding currents in Centropages hamatus. Proceedings of the National Academy of Sciences USA 87: 1653-1657.

Miquelis, A., C. Rougier \& R. Pourriot, 1998. Impact of turbulence and turbidity on the grazing rate of the rotifer Brachionus clyciflorus (Pallas). Hydrobiologia 386: 203-211.

Moore, M. \& J. J. Gilbert, 1987. Age-specific Chaoborus predation on rotifer prey. Freshwater Biology 17: 223-236.

Nagata, T., K. H. Chang \& T. Hanazato, 2006. Impact of invertebrate predators on rotifer populations in lake: field observation and experimental analysis. Verhandlungen der Internationalen Vereinigung für Theoretische und Angewandte Limnologie 29: 2181-2186.

Pace, M., 1986. An empirical analysis of zooplankton community size structure across lake trophic gradients. Limnology and Oceanography 31: 45-55.

Pace, M. L. \& J. D. Orcutt Jr., 1981. The relative importance of protozoans, rotifers, and crustaceans in a freshwater zooplankton community. Limnology and Oceanography 26: 822-830.

Packard, A. T., 2001. Clearance rates and prey selectivity of the predaceous cladoceran Polyphemus pediculus. Hydrobiologia 442: 177-184.

Parma S., 1971. Chaoborus flavicans (Meigen) (Diptera, Chaoboridae). An Autecological Study. Ph.D. dissertation, University of Groningen, Groningen.

Peters, F. \& C. Marrasé, 2000. Effects of turbulence on plankton: an overview of experimental evidence and some theoretical considerations. Marine Ecology Progress Series 205: 291-306.

Pryor, S. C., R. J. Barthelmie \& E. Kjellström, 2005. Potential climate change impact on wind energy resources in northern Europe: analysis using a regional climate model. Climate Dynamics 25: 815-835.

Rothschild, B. J. \& T. R. Osborn, 1988. Small-scale turbulence and plankton contact rates. Journal of Plankton Research 10: 465-474.

Saggio, A. \& J. Imberger, 1998. Internal wave weather in a stratified lake. Limnology and Oceanography 43: 1780-1795.

Salonen, K., M. Järvinen, K. Kuoppamäki \& L. Arvola, 1991. Effects of liming on the chemistry and biology of small 
acid humic lake. In Kauppi, P. \& P. Anttila (eds), Acidification in Finland. Springer-Verlag, Berlin-Heidelberg: 1143-1167.

Sarvala, J., P. Kankaala, P. Zingel \& L. Arvola, 1999. Zooplankton. In Keskitalo, J. \& P. Eloranta (eds), Limnology of Humic waters. Backhuys Publishers, Leiden: 171-191.

Schmid-Araya, J., 1993. Spatial distribution and population dynamics of a benthic rotifer Embata loticeps (Murray) (Rotifera, Bdelleoidea) in the bed sediments of a gravel brook. Freshwater Biology 30: 395-408.

Sluss, T. D., G. A. Cobbs \& J. H. Thorp, 2008. Impacts of turbulence on riverine zooplankton: a mesocosm experiment. Freshwater Biology 53: 1999-2010.

Stemberger, R. S. \& J. J. Gilbert, 1985. Body size, food concentration, and population growth in planktonic rotifers. Ecology 66: 1151-1159.

Stenson, J. A. E., 1990. Creating conditions for changes in prey community structure by Chaoborus spp. in a lake in Sweden. Hydrobiologia 198: 205-214.

Swift, M. C. \& A. Y. Fedorenko, 1975. Some aspects of prey capture by Chaoborus larvae. Limnology and Oceanography 20: 418-425.

Tennekes, H. \& J. I. Lumley, 1972. A First Course in Turbulence. MIT Press, Cambridge.

Vanni, M. J., 1988. Freshwater zooplankton community structure: introduction of large invertebrate predators and large herbivores to a small species community. Canadian Journal of Fisheries and Aquatic Sciences 45: 1758-1770.

Weisner, E. B., J. A. Strand \& H. Sandsten, 1997. Mechanisms regulating abundance of submerged vegetation in shallow eutrophic lakes. Oecologia 109: 592-599.

Williamson, C. E., 1983. Invertebrate predation on planktonic rotifers. Hydrobiologia 104: 385-396.

Wissel, B., W. J. Boeing \& W. C. Ramcharan, 2003. Effects of water color on predation regimes and zooplankton assemblages in freshwater lake. Limnology and Oceanography 48: 1965-1976.

Xie, P., T. Iwakuma \& K. Fujii, 1998. Studies on the biology of Chaoborus flavicans (Meigen) (Diptera: Chaoboridae) in a fish free eutrophic pond, Japan. Hydrobiologia 368: 83-90.

Yan, N. D., W. Keller, H. J. MacIsaac \& L. J. McEachern, 1991. Regulation of zooplankton community structure of an acidified lake by Chaoborus. Ecological Applications 1: 52-65.

Zhou, J., X. Han, B. Qin, C. Caseneva \& G. Yang, 2016. Response of zooplankton community to turbulence in large, shallow Lake Taihu: a mesocosm experiment. Fundamental and Applied Limnology 187: 315-324.

Zhou, J., B. Qin \& X. Han, 2018. The synergetic effects of turbulence and turbidity on the zooplankton community structure in large, shallow Lake Taihu. Environmental Science and Pollution Research 25: 1168-1175. 